\title{
Personality factors in adults and the elderly: A comparative study
}

\author{
Valéria Gonzatti ${ }^{1}$, Adriano Medeiros da Cunha, André Goettems Bastos ${ }^{2}$ \\ Pontifícia Universidade Católica do Rio Grande do Sul, Porto Alegre -RS, Brasil \\ Carmen Moret Tatay \\ Universidad Católica de Valencia San Vicente Mártir, Valencia \\ Irani I. de Lima Argimon, Tatiana Quarti Irigaray \\ Pontifícia Universidade Católica do Rio Grande do Sul, Porto Alegre -RS, Brasil
}

\begin{abstract}
Throughout the life cycle, there is a tendency for individuals to increase and/or decrease some personality traits. The present study aimed to compare the magnitude of the Big Five personality traits among adults and the elderly, and to identify the role of sociodemographic variables (age, schooling, sex and marital status) in their personality traits. This cross-sectional study analyzed 151 participants divided into two groups by age. The elderly group was composed of 78 participants between the ages of 60 and 85 years, and the adult group included 73 participants between 30 and 59 years of age. Participants completed a socio-demographic data sheet and the Five-Factor Inventory-short form (NEO-FFI-R). Results revealed significant differences between the groups associated with the factors Neuroticism, Openness, and Conscientiousness. The adult group showed a significantly greater tendency for higher scores in Neuroticism, Extraversion and Openness. In the elderly group, in turn, there was a greater tendency for individuals to score higher on Conscientiousness. In conclusion, adults tended to present elevated levels of factors such as Neuroticism, Openness, and Conscientiousness, while the elderly presented higher Conscientiousness. These results suggest that personality factors are adjusted according to age group and life events.
\end{abstract}

Keywords: Personality factors, adults, elderly, seniors, NEO-FFI-R.

\section{RESUMO - Fatores de Personalidade em Adultos e Idosos: Um Estudo Comparativo}

Ao longo do ciclo de vida, há uma tendência para os indivíduos a aumentar e/ou diminuir alguns traços de personalidade. O presente estudo objetivou comparar a magnitude dos Cinco Grandes Traços de Personalidade entre idosos e adultos e identificar o papel das variáveis sociodemográficas (idade, escolaridade, sexo e estado civil) em seus traços de personalidade. Este estudo transversal analisou 151 participantes divididos em dois grupos por critérios de idade. Setenta e oito idosos (60 a 85 anos) compuseram o primeiro grupo, e 73 adultos (30-59 anos) formaram o segundo grupo. Os participantes preencheram uma ficha de dados sociodemográficas e o Inventário de Cinco Fatores NEO-FFI-R (NEO-FFI-R), forma curta. Houve diferenças significativas entre os grupos associados aos fatores Neuroticismo, Abertura à experiência e Consciência. No grupo de adultos, houve uma tendência significativamente maior para maiores pontuações no Neuroticismo, Extroversão e Abertura à experiência. No grupo de idosos, por sua vez, houve uma maior tendência para os indivíduos a pontuação mais elevada em Conscienciosidade. Os adultos tendem a apresentar níveis mais elevados de fatores como Neuroticismo, Abertura à experiência e Consciência, enquanto os idosos apresentaram maior Consciência. Esses resultados sugerem que os fatores de personalidade são ajustados de acordo com a faixa etária e os eventos da vida.

Palavras-chave: fatores de personalidade, adultos, idosos, NEO-FFI-R.

\section{RESUMEN - Factores de personalidad en adultos y ancianos: estudio comparativo}

Durante el transcurso de la vida, existe una tendencia de los individuos a aumentar y / o diminuir algunos rasgos de personalidad. El presente estudio tuvo como objetivo comparar la magnitud de los Cinco Grandes Rasgos de Personalidad entre ancianos y adultos e identificar el rol de variables socio-demográficos (edad, escolaridad, sexo y estado civil) en los rasgos de personalidad. Método: En este estudio transversal participaron 151 participantes divididos en dos grupos por criterios de edad, 78 ancianos (60 a 85 años) componían el primer grupo, y 73 adultos (30-59 años) el segundo. Los participantes completaron una ficha de datos socio-demográficos y el Inventario de Cinco Factores (NEO-FFI-R), forma abreviada. Resultados: Hubo diferencias significativas entre los grupos asociados a los factores Inestabilidad Emocional, Extraversión, Apertura a Experiencia y Conciencia. En el grupo de adultos, hubo una tendencia significativa de puntajes más altos en Inestabilidad Emocional, Extraversión y Apertura a experiencia. En el grupo de ancianos, a su vez, hubo mayor tendencia de los individuos a puntajes más altos en Escrupulosidad. Conclusiones: Los adultos tienden a presentar niveles más elevados de factores como Inestabilidad Emocional, Apertura a Experiencia y Conciencia, mientras que los ancianos mostraron mayor Conciencia. Estos resultados sugieren que los factores de personalidad se ajusten de acuerdo con el grupo de edad y los acontecimientos de la vida.

Palabras clave: Factores de Personalidad, adultos, ancianos, NEO-FFI-R. 


\section{Introduction}

Early studies on personality factors indicated that there were few significant changes in personality traits after the age of 30 (Costa \& McCrae, 1997; Costa, Herbst, McCrae, \& Siegler, 2000). However, recent studies indicate that personality traits continue to change throughout the life cycle (Milojev \& Sibley, 2016; Baek et al., 2016; Roberts \& Mroczek, 2008). The Five Factor model (FFM) of personality, also known as Big Five, has been widely used to assess personality change throughout life (Baek et al., 2016). The FFM is also one of the most accepted models of personality, being composed of the factors Extroversion, Agreeableness (or Sociability), Conscientiousness (or Achievement), Neuroticism (or Emotional Stability) and Openness to experience (Nakano, 2014; Nunes, Hutz, \& Giacomoni, 2009).

Neuroticism refers to stress experiences occurred in moments of anxiety, anger, depression and affections related to anxiety. Extroversion is related to sociability and liveliness. Openness to experience is associated with creativeness, aesthetic sensibility, intellectual curiosity and need for variety. Agreeableness corresponds to experiences of confidence, altruism and kindness. As for Conscientiousness, it concerns fulfillment, that is, achievement of goals and values (Fuentes et al., 2010; Löckenhoff, Terracciano, Ferrucci, \& Costa, 2012).

Personality factors change continuously throughout the life cycle both in adult life and in old age (Roberts \& Mroczek, 2008). Changes in the personality factors in elderly are not dramatic, occurring because of life events, genetic aspects, cognitive ability and individuals' goals (Baek et al, 2016). Research report that personality traits change with time, as an adaptive process in response to biological maturation, social roles and expectations or environmental factors (Löckenhoff et al., 2012). Personality traits are associated to important risk factors to health such as smoking, obesity, metabolic and inflammatory markers and indicators of functional health and mortality. That is, an individual's personality is not rigid and immutable and would continue to change to adapt to life's events throughout the entire life span of a person.

Specifically regarding changes in personality factors, the older individuals showed higher levels of Neuroticism, Extroversion and Openness to experience (Masui, Gondo, Inagaki, \& Hirose, 2006). Studies have demonstrated that Neuroticism and Extroversion decline with age, while Agreeableness and Conscientiousness increase. As for Openness to experience, it first increases and then decreases, and the most pronounced changes occur in early and middle adulthood, and the patterns of change are similar in men and women (Costa \& McCrae, 2006; Law, Richmond, \& Kay-Lambkin, 2014; Milojev \& Sibley, 2016).

In a transcultural study involving 50 countries, college students had higher levels of Neuroticism, Extroversion and Openness to experience and lower levels of Agreeableness and Conscientiousness when compared to adults. In this study, Openness to experience was higher in the age range of 18-21 years and decreased after 40 years of age (McCrae \& Terracciano, 2005).

A meta-analysis reported that individuals become more emotionally stable and socially dominant and conscious in middle age. Personality factors such as Agreeableness, Conscientiousness and Openness to experience continue to change after 30 years of age, until old age, and the environment plays a key role on this change. Thus, the development and manifestation of personality factors would not be only a phenomenon of childhood and adolescence, but also of the entire life (Roberts, Walton and Viechtbauer, 2006).

There is a normative tendency for individuals to increase and/or decrease some personality factors during a period of their lives, but there is no guarantee that this change will occur for all individuals, due to particular differences (Roberts, Walton, \& Viechtbauer, 2006). Research has demonstrated that personality factors are influenced by individual, motivational, emotional, behavioral and attitudinal aspects (Costa \& McCrae, 2010; Silva \& Nakano, 2011). A study identified phenotypes of the intersection between social environment, biology and health results. Thus, the personality would operate through a wide range of behavioral, social and biological mechanisms, influencing health throughout life (Chapman et al., 2012).

As far as we are aware, there are few and restricted studies with elderly in Brazil involving the FFM model (Farina, Lopes, \& Argimon, 2016). Thus, the present study aimed to compare FFM results between elderly and adults, and investigate the role of sociodemographic variables (age, education, economic status, gender and marital status) on their personality.

\section{Method}

\section{Design}

This is an exploratory and analytical cross-sectional study.

\section{Participants}

Participants were151 individuals aged 30-85 years recruited in the city of Porto Alegre, Brazil. They were divided in groups: adults, composed of 73 participants aged 30-59 years-old, and elderly, comprising 78 participants aged 60-85 years-old.

Participants were selected in universities and social groups for older people. All participants should be able 
to read, write, and consent in participating in the study. The inclusion criteria for the elderly were: 60 years or older and agree to participate in the study. The exclusion criteria for the group of elderly were: presence of untreated auditory and visual problems that may interfere in the tasks, a score below the Mini Mental State Examination (MMSE) cutoff point (Chaves \& Izquierdo, 1992), and incapacity to read and write. The inclusion criteria for the group of adults were: 30-59 years, be able to read and write, and agree to participate in the study.

\section{Instruments}

Socio-demographic Data Sheet. The socio-demographic data sheet include the following variables: age, gender, marital status, education, economic status (ABEP, 2008), housing status, current occupation, leisure activity, physical and mental health status, use of medication, smoking and drinking (amount and frequency) and physical activity performed.

Miniexame of the Mental State (MMSE). The MMSE is an instrument for the evaluation of cognitive functions. It consists of questions that assess time orientation, location orientation, three-word registration, attention and calculation, remembering three words, language and visual constructive ability. The score can range from zero to 30 points. The Portuguese version, translated by Bertolucci, Brucki, Campacci, end Juliano (1994). In this study, the MMSE will be used to exclude the elderly with scores suggestive of dementia.

Revised Neo Five-Factor Inventory (NEOFFI-R, short form). Consists of 60 affirmative questions to which the participant responds ticking one of five alternatives described, which range from strongly disagree to strongly agree. The five factors Neuroticism, Extroversion, Openness to experience, Agreeableness and Conscientiousness are represented by 12 items that measure each domain. This instrument is suitable for individuals over 18 years of age. Cronbach's alpha for this instrument ranged from 0.70 to 0.83 in the different factors (Costa \& McCrae, 2010).

\section{Procedures}

\section{Data Collection}

This study was approved by the Research Ethics Committee (CEP) of Pontifícia Universidade Católica do Rio Grande do Sul (PUCRS). The elderly group completed separated instrument forms of the MMSE and those who met the inclusion criteria participated in the study. Both groups completed separated NEOFFI-R forms. A team of trained researchers assessed the participants. Participants were individually assessed during meetings with an average duration of 60 minutes.

\section{Data Analysis}

Data description was made using absolute (n) and relative (\%) frequencies for categorical variables, and by mean and standard deviation for continuous variables. The Statistical Package for Social Sciences (SPSS) software, version 20, for Windows was used in the analyzes and set for a $5 \%$ significance level. Statistical strategy used binary logistic regression analysis, using the conditional stepwise backward method (where the initial model considered all variables as potential predictive factors and in each step variables with lower predictive power were excluded, until a final model was defined). Likelihood-ratio test $-2 L L$ or $-2 \log$ was used to assess associations. This strategy was also used to assess the quality of adjustment of the final logistic regression model, as well as of Nagelkerke and HosmerLemeshow's $\mathrm{R}^{2}$ estimates (Nagelkerke, 1991). The likelihood of gradual input of variables to the model was 0.05 ( 0.10 for removal). On the cutoff point, the significance level was 0.50 for a maximum of 20 interactions. Levels of significance lower than 0.01 were considered significant (based on Bonferroni correction) (Nagelkerke,1991).

\section{Results}

Table 1 shows the variables of the socio-demographic profile compared to the high or low values/rate of each personality factor measured by NEO-FFI-R. For the characterization of the results regarding the classification of personality scores, a second type of classification was adopted in which the ratings very low, low and medium were grouped into a new category defined as low. This analytical strategy has been used in order to find correlations and differences between groups (Nagelkerke,1991).

The ratings high and very high were grouped into the second rating category defined as high, which was the target of this study. Thus, the categories for the personality factors of this study were based on two ratings: high and low.

The variable age range was found to be significantly associated with the factors Neuroticism $(p<0.001)$, Openness to experience $(p<0.001)$ and Conscientiousness $(p=0.001)$.

After the classification of personality factors regarding age range through bivariate analysis, we used Binary Logistic Regression analysis to find a final model (table 2). In this strategy, we considered that the dependent variable was the high classification of the personality factors. Independent variables were the socio-demographic variables found to be statistically significant. It should be stressed that the variable 'income' was not included in regression analysis because a considerable percentage of subjects (more than $20 \%$ ) did not inform their economic status. 
Table 1

Frequency of Socio-demographic Variables according to the Personality Factors

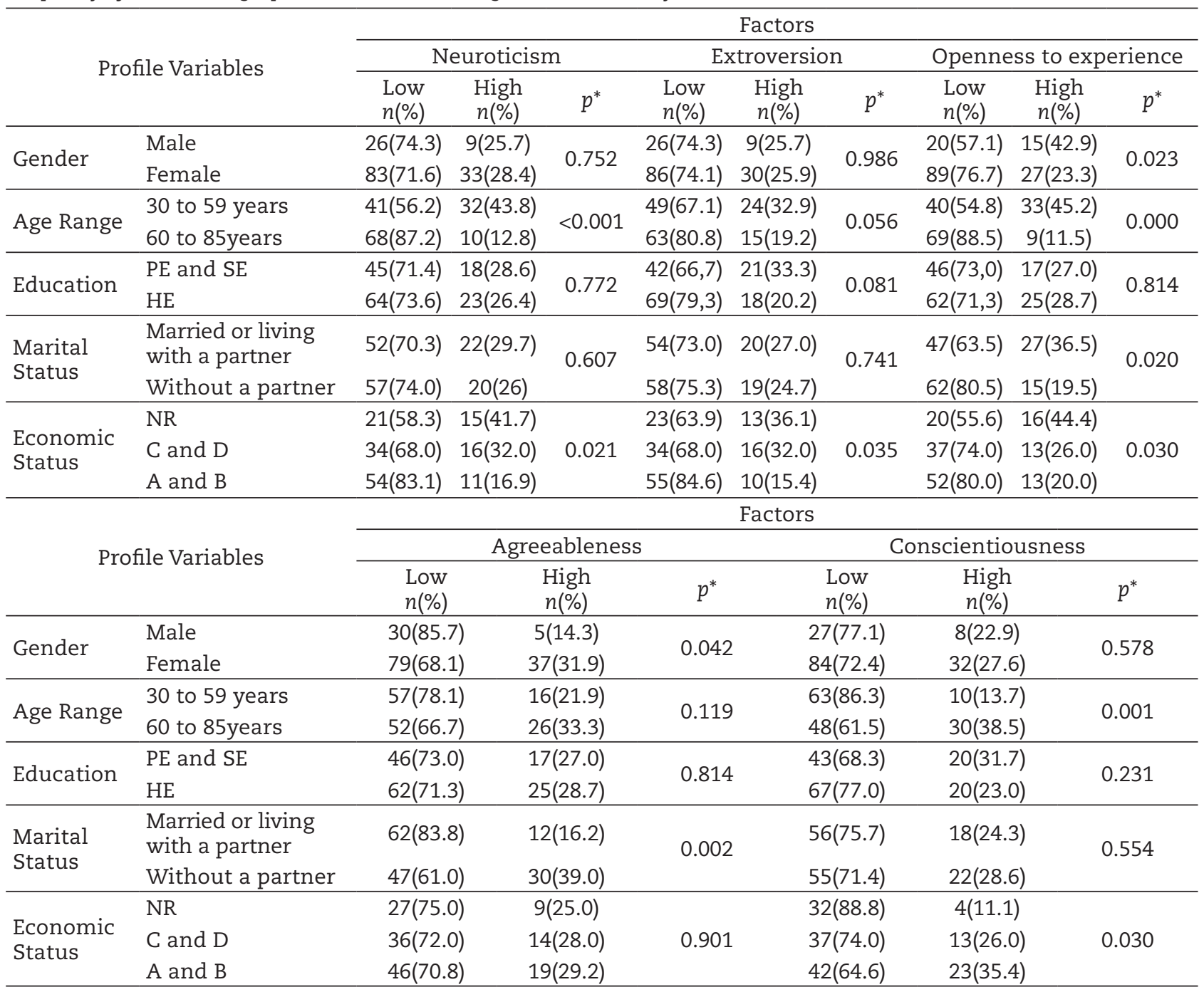

Note. ${ }^{*}=$ Pearson's Chi-square test

The relevant model for Neuroticism indicated that the adults were 5,270 (CI 95\% 2.338-11.879) times more likely to score high on Neuroticism compared to the group of elderly. The initial model explained $17.6 \%$ of the variability considering all the explanatory variables. In the final model, this percentage was $16.7 \%$, considering the adult age range. Regarding the factor Extroversion, it was found that the adults were 2,325 (CI 95\% 1,083-4,994) more likely to score high on this factor than the group of elderly, considering the influence of Primary and Secondary Education $(p=0.059, \mathrm{OR}=2.074$, CI $95 \% 0972 ; 4.426)$. For Extroversion: the initial model explained $9.9 \%$ of the values with all the explanatory variables, and the final model explained $7.7 \%$ with variables adult age range and primary and secondary education, and age range accounted for the higher probability of obtaining high scores for this factor.
Regarding the factor Openness to experience, adult age range was significant for high scores $(p=0.000$, $\mathrm{OR}=6.867$, CI 95\% 2.922; 16.138), as well as male gender $(p=0.034, \mathrm{OR}=2.601$, CI $95 \% 1.075 ; 6.294)$. The initial model explained $26.3 \%$ with all the explanatory variables, and the final model obtained $24.5 \%$ for the variables adult age range and male gender. Thus, adults are 6.8 times more likely to obtain high scores in Openness to Experience compared to elderly, and men are 2.6 times more likely to score high on Openness to Experience than women. Regarding the factor Agreeableness, the initial model explained $12.9 \%$ with all the variables, and the final model obtained $9.9 \%$ for the variable marital status not living with a partner. For Agreeableness, the variable marital status living without a partner was maintained in the final model $(p=0.002$, OR $=3.444$, CI 95\% 1.592; 7.452), while Conscientiousness maintained elderly age range $(p=0.001, \mathrm{OR}=3.812$, CI $95 \% 1.697 ; 8.565)$. 
In both personality factors the variables predicted high scores. For the factor Conscientiousness, in which the initial model explained $14.3 \%$ with all the variables, the final model obtained an explanatory percentage of $11 \%$ for elderly. Thus, it can be inferred that individuals who do not live with a partner are more likely to score high on Agreeableness and elderly are more likely to score high on Conscientiousness compared to adults.

Table 2

Logistic Regression Analysis for Prediction of the Big Five Personality Factors

\begin{tabular}{|c|c|c|c|c|c|c|}
\hline \multirow{2}{*}{$\begin{array}{l} \\
\\
\text { Factors } \\
\text { Neuroticism } \\
\text { Initial model (saturated) }\end{array}$} & \multicolumn{3}{|c|}{ Coefficient of regression } & \multicolumn{3}{|c|}{ Odds } \\
\hline & \multirow[t]{2}{*}{$\mathrm{b}$} & \multirow[t]{2}{*}{$\begin{array}{c}\text { Standard } \\
\text { error }\end{array}$} & \multirow[t]{2}{*}{$\mathrm{p}$} & \multirow[t]{2}{*}{ OR } & \multicolumn{2}{|c|}{ CI 95\% } \\
\hline & & & & & & \\
\hline Age range (adult) & 1.517 & 0.613 & 0.013 & 4.558 & 1.372 & 15.149 \\
\hline Female gender & -0.335 & 0.510 & 0.512 & .716 & 0.263 & 1.944 \\
\hline Education PE and SE & 0.234 & 0.447 & 0.600 & 1.264 & 0.526 & 3.037 \\
\hline Marital status married & 0.143 & 0.449 & 0.751 & 1.153 & 0.478 & 2.783 \\
\hline \multicolumn{7}{|l|}{ Final model } \\
\hline Age range (adult) & 1.662 & 0.415 & 0.000 & 5.270 & 2.338 & 11.879 \\
\hline \multicolumn{7}{|l|}{$\begin{array}{l}\text { Extroversion } \\
\text { Initial model (saturated) } \\
\end{array}$} \\
\hline Age range (adult) & 0.772 & 0.590 & 0.191 & 2.164 & 0.681 & 6.880 \\
\hline Female gender & 0.012 & 0,502 & 0.980 & 1.013 & 0.378 & 2.710 \\
\hline Education PE and SE & 0.578 & 0.435 & 0.184 & 1.782 & 0.759 & 4.183 \\
\hline Marital status married & 0.135 & 0.442 & 0.760 & 1.145 & 0.481 & 2.722 \\
\hline \multicolumn{7}{|l|}{ Final model } \\
\hline Age range (adult) & 0.844 & 0.390 & 0.030 & 2.325 & 1.083 & 4.994 \\
\hline Education PE and SE & 0.730 & 0.387 & 0.059 & 2.074 & 0.972 & 4.426 \\
\hline \multicolumn{7}{|l|}{ Openness } \\
\hline \multicolumn{7}{|l|}{ Male gender } \\
\hline Age range (adult) & 1.918 & 0.662 & 0.004 & 6.804 & 1.859 & 24.908 \\
\hline Sexo masculino & 0.703 & 0.487 & 0.149 & 2.021 & 0.777 & 5.253 \\
\hline Education: Higher education & 0.063 & 0,458 & 0.891 & 1.065 & 0.434 & 2.615 \\
\hline Marital Status: married & 0.481 & 0.463 & 0.299 & 1.618 & 0.652 & 4.012 \\
\hline \multicolumn{7}{|l|}{ Final model } \\
\hline Age range (adult) & 1.927 & 0.436 & 0.000 & 6.867 & 2.922 & 16.138 \\
\hline Male gender & 0.956 & 0.451 & 0.034 & 2.601 & 1.075 & 6.294 \\
\hline \multicolumn{7}{|l|}{ Agreeableness } \\
\hline Age range (Elderly & 0.399 & 0.605 & 0.510 & 1,490 & 0.455 & 4.875 \\
\hline Female gender & 0.651 & 0.569 & 0.252 & 1.918 & 0.629 & 5.847 \\
\hline Education: Higher education & -0.121 & 0.448 & 0.787 & .886 & 0.368 & 2.131 \\
\hline Marital status/ living without a partner & 1.147 & 0.453 & 0.011 & 3.150 & 1.297 & 7.652 \\
\hline \multicolumn{7}{|l|}{ Final model } \\
\hline Marital status: living without a partner & 1.237 & 0.394 & 0,002 & 3.444 & 1.592 & 7.452 \\
\hline $\begin{array}{l}\text { Conscientiousness } \\
\text { Initial model (saturated) }\end{array}$ & & & & & & \\
\hline Age range (Elderly) & 1.162 & 0.683 & 0.089 & 3.197 & 0.838 & 12.202 \\
\hline Female gender & 0.248 & 0.515 & 0.631 & 1.281 & 0.467 & 3.518 \\
\hline
\end{tabular}


Table 2 (continuation)

Logistic Regression Analysis for Prediction of the Big Five Personality Factors

\begin{tabular}{|c|c|c|c|c|c|c|}
\hline \multirow{3}{*}{$\begin{array}{r}\text { Factors } \\
\text { Education PE and SE }\end{array}$} & \multicolumn{3}{|c|}{ Coefficient of regression } & \multicolumn{3}{|c|}{ Odds } \\
\hline & \multirow{2}{*}{$\frac{b}{0.559}$} & \multirow{2}{*}{$\begin{array}{c}\begin{array}{c}\text { Standard } \\
\text { error }\end{array} \\
0.460\end{array}$} & \multirow{2}{*}{$\begin{array}{c}\mathrm{p} \\
0.225\end{array}$} & \multirow{2}{*}{$\frac{\mathrm{OR}}{1.748}$} & \multicolumn{2}{|c|}{ CI 95\% } \\
\hline & & & & & 0.710 & 4.307 \\
\hline Marital status: living without a partner & 0.293 & 0.457 & 0.521 & 1.341 & 0.547 & 3.285 \\
\hline \multicolumn{7}{|l|}{ Final model } \\
\hline Age range (Elderly) & 1.338 & 0.413 & 0.001 & 3.812 & 1.697 & 8.565 \\
\hline
\end{tabular}

\section{Discussion}

The present study aimed to compare the variability of the Big Five Personality traits among elderly and adults and investigate the role of socio-demographic variables (age, education, economic status, gender and marital status) on their personality factors. The results indicated that the adults (30-59 years old) were more likely to obtain high scores in Neuroticism compared to the elderly group (60-85 years old) (Milojev \& Sibley, 2016). Therefore, the 30-59 age range predicts a higher risk of issues related to anxiety, self-criticism and impulsivity (Nostro, Müller, Reid, \& Eickhoff, 2016). Neuroticism concerns adaptation and emotional instability where characteristics such as worry, anxiety, insecurity and stress are present (Costa \& McCrae (2010). This Factor includes negative emotions such as fear, sadness, shame, anger, guilt and sorrow. The result implies that younger individuals would experience more often these emotions.

One hypothesis to explain this finding would be that Neuroticism would decrease with aging. Individuals tend to increase their levels of Neuroticism, especially in young adult life, between 20 and 40 years of age, and older people tend to obtain lower scores (Roberts et al., 2006). Neuroticism declines with age, while Agreeableness and Conscientiousness increase with age (Costa \& McCrae (2006). Likewise, previous studies report that people get more emotionally stable with age, being more able to regulate their emotions (Soto, John, Gosling and Potter (2011) and Roberts, Walton, and Viechtbauer, (2006). Personality factors continue to develop throughout the life cycle, with changes spanning from childhood to old age (Helson, Jones, \& Kwan, 2002; Helson \& Kwan, 2000; Roberts \& Mroczek, 2008; Roberts et al., 2006; Srivastava, John, Gosling, \& Potter, 2003). These changes probably reflect intrinsic maturation processes (McCrae \& Terracciano, 2005) or represent specific adaptations to changes that occur at each stage of the life cycle.

The group of younger adult individuals (30-59 years) was more likely to show tendencies to Extroversion, i.e. sociability and liveliness. Individuals with high Extroversion are more assertive, active, optimistic and talkative (Costa \& McCrae, 2010). Other studies corroborate this finding (Costa \& McCrae 2006; Fonseca,
2006; Roberts et al., 2006), indicating that the individuals tend to become more extroverted, especially in early and middle adulthood (20-40 years) and that older generations tend to obtain lower scores in this factor. In general, Neuroticism tends to increase and Extroversion to decrease with aging (Fonseca, 2006).

In the present study, the male individuals of adults group were more likely to score higher on Openness to experience. This result is in line with other studies that stated that Openness to experience decreases with old age (Roberts et al., 2006). Openness to experience increases in the beginning of the life cycle and then decreases with age, and the most pronounced changes are observed in early adulthood. No differences were found between the genders regarding Openness to Experience in other studies (Costa \& McCrae, 2006; Roberts et al., 2006).

Previous studies pointed out that Oppenness to experience is strongly correlated to cognitive functioning (Costa \& McCrae, 2010; Graham \& Lachman, 2014). This personality factor promotes patterns of behavior that cause individuals to engage in learning and leisure activities (Booth, Schinka, Brown, Mortimer, \& Borenstein, 2006). Thus, individuals with higher scores in Openness to experience would be more prone to creativeness, intellectual curiosity and to engage in learning activities (Booth et al., 2006). Thus, this would be a key factor for maintaining the cognitive abilities during the process of aging (Chapman et al., 2012; Fonseca, 2006).

Regarding the factor Agreeableness, only the variable marital status living without a partner was maintained in the final regression model. Costa and McCrae (2010) explain that Agreeableness concerns interpersonal tendencies of individuals that are more outspoken, altruistic, cooperative, courteous and friendly with other peoples. It has an ambiguous role due to its high amount of social desirability.

It was also observed that the variable with the highest explanatory power for high score in the Conscientiousness factor was elderly age range. Thus, the elderly are more likely to score high on Conscientiousness than the adults. According to Costa end McCrae (2010), Conscientiousness comprises issues related to organization, persistence and motivation, contrasting with laziness and carelessness. The individuals with high levels of Conscientiousness are conscientious, punctual and 
reliable. Individuals with low Conscientiousness are less reliable and less careful at work. This finding corroborates the results obtained in other studies (Costa \& McCrae, 2006; McCrae \& Terracciano, 2005; Roberts, et al., 2006) that show lower levels of Conscientiousness in younger individuals. Conscientiousness increases with age (Costa \& McCrae, 2006), regardless of the educational level (McCrae \& Terracciano, 2005).

Although this is a descriptive and exploratory study, it was found that regardless of the different variables listed for the Big Five Personality Factors, age range was the variable that best explained the differences between the age groups. Therefore, based on the findings of this study, it can be concluded that adults aged 30-59 years were more likely to score high on Neuroticism, Extroversion and Openness to experience compared to the elderly individuals (60-85 years). Besides, the elderly were more likely to score high on the factor Conscientiousness compared to the adults. These results allow inferring that personality factors are adjusted according to the age range of the individual, as an adaptation to life events.

One limitation of this study is its cross-sectional design. Another limitation concerns the impossibility of including the 'income' in regression analysis, since more than $20 \%$ of the subjects did not inform their economic status. Despite these limitations, interesting and significant results were obtained. They indicate a possible relationship between age and the Big Five Personality Factors. For all these reasons, we suggest further studies with longitudinal designs, in order to follow the development of personality factors throughout the entire life cycle.

\section{References}

Associação Brasileira de Empresas de Pesquisa (2008). Critério de classificação econômica Brasil. São Paulo: ABEP. Recuperado em 01 outubro, 2012 de http://www.abep.org/criterio-brasil

Baek, Y., Martin, P., Siegler, I. C., Davey, A., \& Poon, L. W. (2016). Personality Traits and Successful Aging Findings From the Georgia Centenarian Study. The International Journal of Aging and Human Development, 83(3), 207-227.doi: 10.1177/0091415016652404

Bertolucci, P. H. F., Brucki, S. M. D., Campacci, S. R., \& Juliano, Y. (1994). O mini-exame do estado mental em uma população geral: Impacto da Escolaridade. Arquivos de Neuro-Psiquiatria, 52(1), 1-7.

Booth, J., Schinka, J., Brown, L., Mortimer, J., \& Borenstein, A. (2006). Five-factor personality dimensions, mood states, and cognitive performance in older adults. Journal of Clinical and Experimental Neuropsychology, 28(5), 676-683.

Chapman, B., Duberstein, P., Tindle, H. A., Sink, K. M., Robbins, J., \& Tancredi, D. J., for the Gingko Evaluation of Memory (GEM) Study Investigators. (2012). Personality predicts cognitive function over seven years in older persons. The American Journal of Geriatric Psychiatry, 20(7), 612-621. doi: 10.1097/JGP.0b013e31822cc9cb

Chaves, M. L., \& Izquierdo, I. (1992). Differential diagnosis between dementia and depression: a study of efficiency increment. Acta Neurologica Scandinavia, 11, 412-429.

Costa, P. T., \& McCrae, R.R. (1997). Longitudinal stability of adult personality. In R. Hogan, J. Johnson, \& S. Briggs (Eds.), Handbook of personality psychology (pp. 269-292). San Diego: Academic Press.

Costa, P. T., Herbst, J.H., McCrae, R. R., \& Siegler, I. C. (2000). Personality at midlife: Stability, intrinsic maturation, and response to life events. Assessment, 7(4), 365-378.

Costa Jr, P. T., \& McCrae, R. R. (2006). Age changes in personality and their origins: Comment on Roberts, Walton, and Viechtbauer (2006). Psychological bulletin, 132(1):26-28. doi: 10.1037/0033-2909.132.1.26

Costa Jr, P. T., \& McCrae, R. R. (2010). NEO PI-R: Inventário de personalidade NEO revisado e inventário de cinco fatores NEO revisado NEOFFI-R [versão curta]. São Paulo, SP: Vetor.

Farina, M., Fernandes Lopes, R. M., \& de Lima Argimon, I. I. (2016). Perfil de idosos através do modelo dos cinco fatores de personalidade (Big Five): Revisão sistemática. Diversitas: Perspectivas en Psicología, 12(1), 97-108.

Fonseca, A. (2006). O envelhecimento, uma abordagem psicológica. Lisboa: Universidade Católica Editora, $2^{\text {a }}$ Edição.

Fuentes, D., Moreno, C., Sassi, F., Frambati, L., Lacerda, J., \& Malloy-Diniz, L. F. (2010). Avaliação da personalidade e sua contribuição à avaliação neuropsicológica. In L. F. Malloy-Diniz, D. Fuentes, P. Mattos \& N. Abreu, (Eds.), Avaliação Neuropsicológica (pp.198-208). Porto Alegre: ARTMED.

Graham, E. K., \& Lachman, M. E. (2014) Personality traits, facets and cognitive performance: Age differences in their relations. Personality and Individual Differences, 59, 89-95.

Helson, R., \& Kwan, V.S. (2000). Personality development in adulthood: The broad picture and processes in one longitudinal sample. Advances in personality psychology, 1, 77-106.

Helson, R., Jones, C., \& Kwan, V. S. Y. (2002). Personality change over 40 years of adulthood: Hierarchical linear modeling analyses of two longitudinal samples. Journal of Personality and Social Psychology, 83, 752-766.

Law, J., Richmond, R. L., \& Kay-Lambkin, F. (2014). The contribution of personality to longevity: Findings from the Australian Centenarian Study. Archives of gerontology and geriatrics, 59(3), 528-535.

Löckenhoff, C. E, Terraciano, A., Ferrucci, L., \& Costa, P. T. (2012). Five-factor personality traits and age trajectories of self-rated health: The role of question framing. Journal of Personality, 80(2), 375-401.

Masui, Y., Gondo, Y., Inagaki, H., \& Hirose, N. (2006). Do personality characteristics predict longevity? Findings from the Tokyo Centenarian Study. Age, 28(4), 353-361.

Milojev, P., \& Sibley, C. G. (2016). Normative personality trait development in adulthood: A 6-year cohort-sequential growth Model. Journal of personality and social psychology. 
McCrae, R. R., \& Terracciano, A. (2005). Universal features of personality traits from the observer's perspective: Data from 50 cultures. Journal of personality and social psychology, 88(3), 547.

Nagelkerke, N. J. D. (1991). A note on a general definition of the coefficient of determination. Biometrika, 78, 691-692.

Nakano, T. C. (2014). Personalidade: Estudo comparativo entre dois instrumentos de avaliação. Estudos de Psicologia (Campinas), 31(3), 347357.

Nostro, A. D., Müller, V. I., Reid, A. T., \& Eickhoff, S. B. (2016). Correlations between personality and brain structure: A crucial role of gender. Cerebral Cortex.

Nunes, C. H. S., Hutz, C. S., \& Giacomoni, C. H. (2009). Associação entre bem-estar subjetivo e personalidade no modelo dos cinco grandes fatores. Avaliação Psicológica, 8(1), 99-108.

Roberts, B. W., \& Mroczek, D. (2008). Personality trait change in adulthood. Current Directions in Psychological Science, 17(1), $31-35$.

Roberts, B. W., Walton, K. E., \& Viechtbauer, W. (2006). Patterns of mean-level change in personality traits across the life course: A meta-analysis of longitudinal studies. Psychological bulletin, 132(1), 1-25.

Silva, I. B., \& Nakano, T. C. (2011). Modelo dos cinco grandes fatores da personalidade: Análise de pesquisas. Avaliação Psicológica, 10(1), $51-62$.

Soto, C. J., John, O. P., Gosling, S. D., \& Potter, J. (2011). Age differences in personality traits from 10 to 65: Big-Five domains and facets in a large cross-sectional sample. Journal of Personality and Social Psychology, 100(2), 330-348.

Srivastava, S., John, O. P., Gosling, S. D., \& Potter, J. (2003). Development of personality in early and middle adulthood: Set like plaster or persistent change? Journal of Personality and Social Psychology, 84, 1041-1053.

\section{Sobre os autores}

Valéria Gonzatti é Psicóloga, Mestre e Doutoranda em Psicologia pela Pontifícia Universidade Católica do Rio Grande do Sul (PUC-RS), psicóloga colaboradora do CRPRS - $7^{\text {a }}$ Região e professora convidada da Pontifícia Universidade Católica do Rio Grande do Sul.

Adriano Medeiros da Cunha é graduado em Psicologia pela PUC-RS.

André Goettems Batos é Psicólogo, Doutor em Psicologia pela UFRGS, e Mestre em Psicologia Clínica pela PUCRS. Participa do Programa Nacional de Pós-Doutorado da CAPES (PNPD/CAPES), professor e supervisor titular do Contemporâneo: Instituto de Psicanálise e Transdisciplinaridade (CIPT), atuando também como Coordenador Geral do Núcleo de Estudos dos Transtornos de Humor (NETH).

Carmen Moret Tatay é Psicóloga e Doutora em Matemáticas aplicadas na ciência cognitiva pela Universitat Politécnica de València. Professora de ciência cognitiva e metodologia e diretora do grupo de pesquisa Métodos de investigação em ciências do comportamento e inovação tecnológica em Valencia (Espanha) da Universidad Católica de Valencia, San Vicente Mártir.

Irani Iracema de Lima Argimon é Psicóloga e Doutora em Psicologia pela PUC-RS. Ccoordenadora do Grupo de Pesquisa Avaliação e Intervenção no Ciclo Vital, do PPGP da PUC-RS desde 2004. Bolsista Produtividade CNPq. Professora Titular dos cursos de Graduação e de Pós-Graduação em Psicologia da PUC-RS.

Tatiana Quarti Irigaray é Psicóloga, Doutora em Gerontologia Biomédica pela PUC-RS, possui Pós-Doutorado em Psicologia pela PUC-RS. Coordenadora do Programa de Pós-Graduação em Psicologia da Escola de Ciências da Saúde da PUC-RS, Professora adjunta do curso de graduação em psicologia e coordenadora do grupo de pesquisa Avaliação, Reabilitação e Interação Humano-Animal (ARIHA). 